\title{
Diet Selection of Heteracris littoralis in a Cultivated Environment, Mzab Valley, Septentrional Sahara, Algeria
}

Youcef Zergoun, Laboratoire des Bio-ressources Sahariennes: Préservation et Valorisation, Département des Sciences Agronomiques, Faculté des Sciences de la Nature et de la Vie et Sciences de la Terre. Université Kasdi Merbah, 30000 Ouargla, Algeria / Département des Sciences Agronomiques, Faculté des Sciences de la Nature et de la Vie et Sciences de la Terre, Université de Ghardaïa, 47000 Ghardaïa, Algeria, Omar Guezoul, Makhlouf Sekour, Laboratoire des Bioressources Sahariennes: Préservation et Valorisation, Département des Sciences Agronomiques, Faculté des Sciences de la Nature et de la Vie et Sciences de la Terre, Université Kasdi Merbah, 30000 Ouargla, Algeria, Noureddine Bouras, Département de Biologie, Faculté des Sciences de la Nature et de la Vie et Sciences de la Terre, Université de Ghardaïa, 47000 Ghardaïa, Algeria, and Michael D. Holtz, Field Crop Development Centre, Alberta Agriculture and Forestry, Alberta T4L1W8, Canada https://doi.org/10.52543/tipp.15.2.4

(Algeria/Canada)

\begin{abstract}
Zergoun, Y., Guezoul, O., Sekour, M., Bouras, N., and Holtz, M.D. 2020. Diet selection of Heteracris littoralis, in a cultivated environment, Mzab valley, Septentrional Sahara, Algeria. Tunisian Journal of Plant Protection 15 (2): 69-80.
\end{abstract}

This paper presents the results of a study on the diet of Heteracris littoralis in an agro-ecosystem at Mzab valley, Ghardaïa Province, Northern Sahara, Algeria. The diet was determined by the analysis of plant fragments in the feces of $H$. littoralis sampled in the field. The studied grasshopper consumed 12 of the 30 plant species found in the cultivated environment. The results showed that the locust predominantly fed on a few plants, such as Lagenaria siceraria and Solanum lycopersicum, although their diet includes over 12 plant species. Its food niche breadth was narrow (0.51), with a selectivity index of 0.61 for females, 0.52 for males and 0.42 for larvae. The plants consumed by the two sexes and larvae were not significantly different. This study suggests that Eyprepocnemidinae is a polyphagous grasshopper species, in spite of pronounced preference towards Cucurbitaceae and Solanaceae. This property results in a low Berger-Parker index value (0.24). Results are of great significance, increasing the understanding of insect herbivore feeding behavior and how to control the damage caused by this Orthoptera.

Keywords: Algeria, food selection, Heteracris littoralis, Mzab valley, niche breadth, Septentrional Sahara

Corresponding author: Noureddine Bouras

Email: noureddine_bouras@yahoo.fr

Accepted for publication 03 November 2020
There are more than 500 species of acridids (Orthoptera: Acridoidea) that can cause damage to pastures and crops (Duranton et al. 1982), and about 50 are considered major pests. Although locust outbreaks 
are now better controlled and invasions are often shorter and reduced in extent, large outbreaks of both locusts and grasshoppers continue to occur in many parts of the world (Zhang et al. 2019). In Algeria, there are many locust and grasshopper species, which periodically cause significant damage on crops (Doumandji and Doumandji-Mitiche 1994). Among them, Heteracris littoralis (Rambur, 1838) occurs mainly in area of the Mzab valley, Northern Sahara, Algeria where it constitutes a major problem to several cultivated plants. Although many common species have been studied exhaustively due to their significance as agricultural pests, information on Acridid species showing a high degree of feeding specialization remains sparse. However, quantitative data on the feeding and the amount consumed by $H$. littoralis in Algeria and the Sahara are practically absent because the only species that are wellstudied are the gregarious and economically important species such as the migratory locust Locusta migratoria, the desert locust Schistocerca gregaria, and the Moroccan locust Dociostaurus maroccanus. The geographic distribution of $H$. littoralis is around the Mediterranean (southern Spain, Turkey); North Africa (Libya, Egypt, Saharan oases); Sahel (from Mauritania to Sudan); Middle East (Iraq and Iran); Arabian Peninsula; Afghanistan; Pakistan; South West Asia; India; Kazakhstan; Turkmenistan (Louveaux et al. 2020). H. littoralis is an important pest of crops in East Africa and feeds on many different plants, causes moderate to severe damage to sorghum, rice, cotton and vegetable crops (Duranton et al. 1982). This Eyprepocnemidinae is considered one of the most harmful pests of different cultivated crops in
Egypt. Its economic importance comes from attacking many cultivated crops, vegetables and even trees, and the resulting great losses in quantity and quality of the attacked crop. In some cases, thousands of cultivated hectares may be attacked by grasshopper swarms leaving it as a desolate desert (Sharaby et al. 2010; Sharaby et al. 2012; Sharaby et al. 2013; Sabbour 2014).

This study was undertaken following field observations of an apparent preference by the grasshopper $H$. littoralis as indicated by the considerable damage on Cucurbitaceae and Solanaceae. Interest in the importance of Cucurbitaceae and Solanaceae in the valley agriculture and the special relationship of these crops and $H$. littoralis led to a field study of this Eyprepocnemidinae diet in this agrosystem in the Northern Algerian Sahara. Therefore, this investigation was conducted aiming: (i) to estimate the diet composition of $H$. littoralis using the fecal analysis technique, (ii) to analyze on grasshoppers food selectivity and trophic niche breadth, and (iii) to characterize the damage caused by this Orthoptera.

\section{MATERIALS AND METHODS Study area.}

The study was conducted between June and September of 2019 at a cultivated environment in the Mzab valley (Ghardaïa), Northern Sahara, Algeria (Fig. 1). The region is situated at $32^{\circ} 26^{\prime}-32^{\circ} 30^{\prime} \mathrm{N}$ in latitude and $3^{\circ} 36^{\prime}-3^{\circ} 43^{\prime} \mathrm{E}$ in longitude and at an elevation of $558 \mathrm{~m}$. Vegetative biomass at this site was dominated by the date palm (Phoenix dactylifera), citrus (Citrus sinensis), olive trees (Olea europaea), vegetable crops such as Lagenaria siceraria, Cucurbita maxima, Cucumis melo, Capsicum 
annuum, Solanum melongena and Solanum lycopersicum, while common grasses included Cynodon dactylon, Setaria verticillata and Polypogon monspeliensis (Zergoun et al. 2018a, 2019). Climatically, the area is characterized by low rainfall (Zergoun et al. 2018b). Average annual precipitation is about $65 \mathrm{~mm}$, and the annual average temperature $22.3{ }^{\circ} \mathrm{C}$. Air temperatures can fall as low as $4{ }^{\circ} \mathrm{C}$ in December and reaches $42{ }^{\circ} \mathrm{C}$ in July (ONM 2019). Soil type is Sandy-loamy soil.

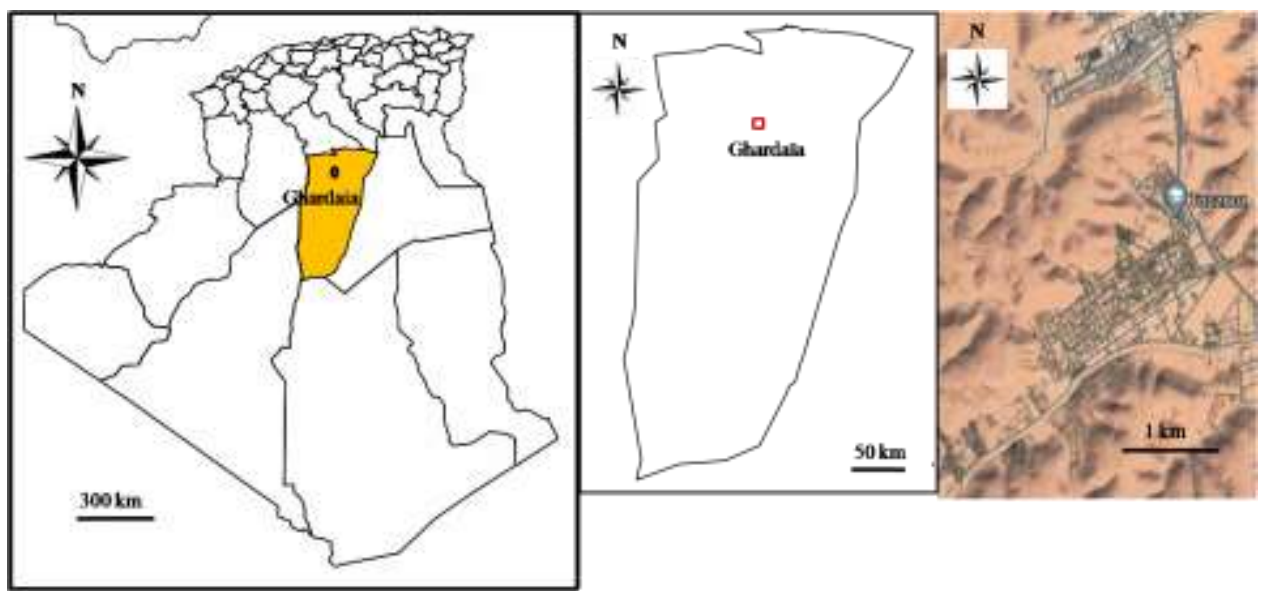

Fig. 1. Geographic location of the studied sites in the Mzab Valley (Ghardaïa), Septentrional Sahara (Algeria).

\section{Vegetation sampling.}

We delimited a $500 \mathrm{~m}^{2}(10 \mathrm{~m} \times$ $50 \mathrm{~m})$ sampling surface, in which we recorded the percentage cover of each plant species and was estimated following the methods described by Duranton et al. (1982). The plant species were determined by using the flora of Quezel and Santa (1962-1963).

\section{Diet sampling.}

For 4 months, 75 individuals of H. littoralis (25 males, 25 females and 25 larvae) were collected biweekly, in the morning after 9 a.m, and their feces were preserved for diet analysis. Feces were stored in plastic tubes, one tube per grasshopper. Age and sex of each grasshopper was noted on each sample. Analysis of the diet was performed by feces content analysis, which is based on the recognition of epidermal fragments of the consumed plants contained in the feces, using a light microscope (Launois-Luong 1976). The determination is made by comparing to reference epidermises, prepared from fresh plants collected from the study site.

\section{Data analysis.}

Frequency of occurrence was calculated for each food item present based on the number of fields containing a particular food item. Frequency was converted to relative frequency. The Diet Selectivity Index (SI) for field collected $H$. littoralis was determined according to the formula: SI $=\mathrm{D} / \mathrm{P}$, where $\mathrm{D}=$ percentage of a plant 
species consumed and $\mathrm{P}=$ percentage of biomass of the same species in the environment (Wang 2001). A SI of 1 indicates that the plant species was consumed in the same ratio as its availability (i.e., no preference). A SI > 1 indicates that a greater proportion of that plant species was eaten than was available, and thus was a preferred food for the herbivore. A SI $<1$ indicates that the herbivore ate a smaller proportion of that species, than was presented, and thus that plant was less preferred by the herbivore. Sampling adequacy was determined using Lehner's formula (Lehner 1996): $Q=1-N_{1} / I$, ranging from 0 to 1 , where $N_{1}$ is the number of the food components occurring only once, and $\mathrm{I}$ is the total number of the food components.

Todetermine the consumption rate ( $\mathrm{T} \%)$ of $H$. littoralis, the method proposed by Doumandji et al. (1993) has been used to estimate the surfaces of the fragments contained in the feces. $\mathrm{T}=\mathrm{S} / \Sigma \mathrm{S} * 100$. T: the consumption rate of a given plant species is the percentage of leaf area of this species ingested by $H$. littoralis, by comparison to the total leaf area ingested. $S$ : the average area of a plant species consumed by $\mathrm{N}$ individuals.

Population-level diet breadths were quantified using the Levins (1968) measure that is estimated by measuring the uniformity of distribution of individuals among the resource states. He suggested one way to measure this was: $\mathrm{B}=1 / \Sigma \mathrm{pj} 2$, where: $\mathrm{B}=$ Levins' measure of niche breadth, $\mathrm{pj}=$ fraction of items in the diet that are of food category j. Hurlbert (1978) suggested the following measure for standardized niche breadth: $\mathrm{BA}=\mathrm{B}-1 / \mathrm{n}-1$, where $\mathrm{BA}=$ Levins' standardized niche breadth, B = Levins' measure of niche breadth, $\mathrm{n}=$ Number of possible resource states. The second, the Shannon-Weaver information-theoretic index (Pielou 1969), was used: $\mathrm{H}^{\prime}=-\sum_{i=1}^{s} \mathrm{Pi} * \ln \mathrm{Pi}$, where $\mathrm{Pi}$ represents the proportion in which each resource state is used by the species. $\mathrm{H}^{\prime}$ weights the relative abundance of different resources utilized by the grasshopper species as a whole (Otte and Joern 1977). To determine the level of food specialization of males, females and larvae, the Berger-Parker dominance index (d) was calculated by the following formula (Magurran 1988): $\mathrm{d}=\mathrm{Ni} \max / \mathrm{N}$, where $\mathrm{N}$ is the number of all recorded food components (taxa), and Ni max is the number of specimens from taxon $\mathrm{i}$ (the most numerous taxon in the diet). The Berger-Parker index (d) varies between $1 / \mathrm{N}$ and 1 . A value closer to 1 indicates higher specialization in the choice of food, while a value closer to $1 / \mathrm{N}$ is typical of species that are general feeders (polyphagous) (Capello et al. 2012). We used Kruskal-Wallis non-parametric one-way analysis of variance to test for differences of plant fragments frequency found in the feces of males, females and larvae. $P$ values of 0.05 or smaller were interpreted as significant. All statistics were performed using statistical package Past 3.4 (Hammer et al. 2014). All data transformations were done in Excel.

\section{RESULTS}

Thirty plant species belonging to 15 families occurred in the cultivated environment. The most frequent family was represented by the Poaceae with 11 species $(36.7 \%$ of the total number of plant species). The Cucurbitaceae and the Solanaceae (10\% each) followed the Poaceae in importance. The Asteraceae was represented by two species $(6.7 \%)$. The 11 remaining families were 
represented by a single species $(3.3 \%$ each). The plant cover of this site was above average $(63.89 \%)$. This indicates the greater probability of finding considerable number of Orthoptera within the habitat. Analysis of feces from 75 individuals of $H$. littoralis shows the diet was $83.3 \%$ Dicotyledons and only $16.7 \%$ Monocotyledons. Among thirty species found in the habitat, only twelve have been identified at least once in feces as indicated in Table 1.

L. siceraria made up $23.96 \%$ in the feces of the grasshoppers but constituted $4.02 \%$ of the percentage cover in the habitat. S. lycopersicum accounted for $20.14 \%$ in the feces of the acridid and only $4.95 \%$ of the percentage cover. $C$. maxima made up $14.58 \%$ in the feces of the insects but constituted $3.77 \%$ of the percentage cover in the site. The results of the diet selectivity index revealed that, this Orthoptera has a definite selectivity for seven cultivated plants; this marked selectivity for food crops could be attributed to the ability of these plants to strongly support the growth and development of $H$. littoralis.

Quantitatively, L. siceraria is well consumed, characterized by a consumption rate of $19.78 \%$, followed by $S$. lycopersicum $(18.27 \%), \quad C$. maxima (14.31\%), C. melo (12.21\%), and $S$. melongena (11.36\%); however, other plant species are less consumed.

The percentages cover of food plants in the environment does not appear to affect the relative frequency of plant fragments found in the feces. However, a comparison of relative frequency of plant fragments found in the feces with the percentage cover of food plants in the habitat using the nonparametric Kruskal-Wallis test did not reveal any significant differences (Kruskal-Wallis test, $\chi^{2}=0.85, P$-value $=0.3556)$. The same was true for a comparison of the diet selectivity index with the percentage cover of food plants in a cultivated environment (KruskalWallis test, $\chi^{2}=1.47, P$-value $=$ 0.2253).

In terms of a composite diet for H. littoralis, cultivated plants constituted $92.36 \%$, forbs constituted $3.82 \%$ of the diet, and grasses contributed by $3.82 \%$ of the diet. Fecal pellet analysis of this Acrididae showed that $2.67 \%$ of both larvae and adults had eaten only one plant, $54.67 \%$ had eaten 2 plants, and $42.67 \%$ ate 3 plants. The analysis of fecal pellets demonstrated that over $97 \%$ of the individual of this Eyprepocnemidinae, had diversified their diet, eating 2 to 3 plants species, while the rest of the grasshoppers had eaten only one plant species. The adults ate 12 plant species each; on the other hand, only 7 plants species were selected by larvae of $H$. littoralis in the following order of preference: $S$. lycopersicum, L. siceraria, C. maxima, S. melongena, Mentha pulegium, $C$. melo and C. annuum (Fig. 2).

The sampling adequacy is considered sufficient (0.97). The trophic niche breadth of females has the highest value $(0.61)$, followed by males $(0.52)$ and larvae showed the lowest value (0.42) (Table 2). This is confirmed by the values of the Shannon-Wiener Measure: female (2.20), males (2.10) and larvae (1.50). 
Table 1. Plant species found in the diet of Heteracris littoralis, in a cultivated environment, Mzab valley (Septentrional Sahara, Algeria)

\begin{tabular}{|c|c|c|c|c|c|}
\hline Families & Vegetable species & $\mathrm{C}(\%)$ & $\mathbf{F}(\%)$ & SI & $\mathbf{T}(\%)$ \\
\hline Arecaceae & Phoenix dactylifera & 8.48 & - & - & - \\
\hline Rutaceae & Citrus sinensis & 3.77 & - & - & - \\
\hline Oleaceae & Olea europaea & 2.83 & - & - & - \\
\hline Vitaceae & Vitis vinifera & 2.12 & - & - & - \\
\hline \multirow{3}{*}{ Cucurbitaceae } & Lagenaria siceraria & 4.02 & 23.96 & 5.96 & 19.78 \\
\hline & Cucurbita maxima & 3.77 & 14.58 & 3.87 & 14.31 \\
\hline & Cucumis melo & 2.51 & 11.81 & 4.70 & 12.21 \\
\hline \multirow{3}{*}{ Solanaceae } & Capsicum annuиm & 2.54 & 6.94 & 2.73 & 8.50 \\
\hline & Solanum melongena & 2.54 & 9.03 & 3.55 & 11.36 \\
\hline & Solanum lycopersicum & 4.95 & 20.14 & 4.07 & 18.27 \\
\hline Lamiaceae & Mentha pulegium & 3.14 & 5.90 & 1.88 & 6.57 \\
\hline \multirow{11}{*}{ Poaceae } & Cynodon dactylon & 7.85 & 2.08 & 0.27 & 2.86 \\
\hline & Setaria verticillata & 4.91 & 1.74 & 0.35 & 2.69 \\
\hline & Polypogon monspeliensis & 0.49 & - & - & - \\
\hline & Digitaria commutata & 0.39 & - & - & - \\
\hline & Dactyloctenium aegyptium & 0.34 & - & - & - \\
\hline & Anisantha sterilis & 0.25 & - & - & - \\
\hline & Lolium multiflorum & 0.29 & - & - & - \\
\hline & Hordeum murinum & 0.25 & - & - & - \\
\hline & Agrostis stolonifera & 0.39 & - & - & - \\
\hline & Stipagrostis plumosa & 0.34 & - & - & - \\
\hline & Phragmites australis & 0.57 & - & - & - \\
\hline Cyperaceae & Cyperus rotundus & 0.39 & - & - & - \\
\hline \multirow{2}{*}{ Asteraceae } & Sonchus oleraceus & 0.44 & - & - & - \\
\hline & Crepis capillaris & 1.23 & 1.04 & 0.59 & 0.93 \\
\hline Convolvulaceae & Convolvulus arvensis & 0.29 & - & - & - \\
\hline Amaranthaceae & Amaranthus hybridus & 0.35 & - & - & - \\
\hline Zygophyllaceae & Tribulus terrestris & 2.94 & 1.74 & 0.88 & 1.18 \\
\hline Polygonaceae & Rumex vesicarius & 0.32 & - & - & - \\
\hline Malvaceae & Malva parviflora & 1.18 & 1.04 & 0.85 & 1.35 \\
\hline Total / Rate & 30 & 63.89 & 100 & - & 100 \\
\hline
\end{tabular}

C (\%): Percentage cover, F (\%): Relative frequency of plant fragments found in the feces, SI: The diet selectivity index, T (\%): consumption rate, (-): Absent species. 


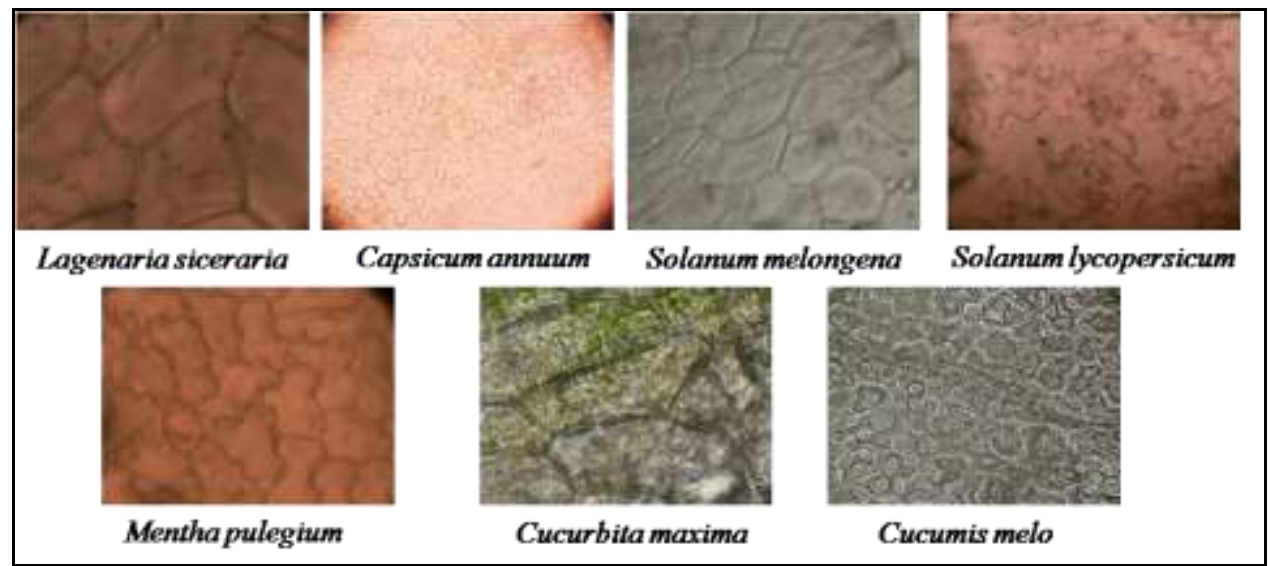

Fig. 2. Epidermis of the main cultivated plants found in the feces of Heteracris littoralis (magnification: $\times 40$ ).

Table 2. Different ecological indices applied to diet of Heteracris littoralis in agriculture ecosystem in Mzab valley (Septentrional Sahara, Algeria)

\begin{tabular}{l|c|c|c|c}
\hline \multicolumn{1}{c|}{ Index } & Males(M) & Females (F) & Larvae(L) & $\begin{array}{c}\text { All individuals } \\
(\mathbf{M}+\mathbf{F}+\mathbf{L})\end{array}$ \\
\hline Number of specimens & 25 & 25 & 25 & 75 \\
Number of plants consumed & 12 & 12 & 7 & 12 \\
Diet breadths (B A $_{\text {) }}$ & 0.52 & 0.61 & 0.42 & 0.51 \\
Diversity index (H') & 2.1 & 2.2 & 1.5 & 2.08 \\
Berger-Parker index (d) & 0.24 & 0.2 & 0.41 & 0.24 \\
\hline
\end{tabular}

The Berger-Parker index of larvae showed a value of 0.41 (Table 2); because the majority of the diet consists of $S$. lycopersicum $(41 \%)$ and $L$. siceraria $(32 \%)$ and only $27 \%$ of the diet consists of the remaining five plants, thus showing plant specificity. The Berger-Parker index of males and female showed considerably low values (0.24 and 0.20) (Table 2), because most of the diet distributed over four plant species were: L. siceraria (24-20\%), C. maxima (17-16\%), S. lycopersicum (15\% each), C. melo (14\% each), thus showing a low specificity.

\section{DISCUSSION}

In our study, $H$. littoralis consumed 12 plant species and mainly selected Cucurbitaceae and Solanaceae, such as L. siceraria, C. maxima, $S$. lycopersicum and $S$. melongena. This preference may in part be due to the behavioral characteristics of the grasshopper in its particular habitat. Field observations have indicated that this Caelifera is primarily vegetation dwelling, feeding and roosting on vegetation at all times. Only 7 plant species were selected by larvae of this grasshopper. This may be due to the larvae having a more limited range of 
movement, due to a lack of fully formed wings, which could restrict their diet. The present study showed that plants of the Cucurbitaceae and Solanaceae were the preferred food source. H. littoralis may act as a pest of some of the economically important plant species of those families in the study area. Since there has been no previous study of this nature involving phytophagous Acridids of the Mzab valley, the present finding brings to light some observations that may have major agro-economic importance. At Beni Abbes oasis, South-West of Algeria, the analysis of the feeding diet of $H$. annulosa shows that it consumes only six Poaceae (Ould Elhadj 1999). In East Africa, $H$. littoralis causes moderate to severe damage to sorghum, rice, cotton and vegetable crops (Duranton et al. 1982). Previous research in Egypt has shown that $H$. littoralis is more common in cultivated crops, vegetables and even trees, feeding on those and causing great losses in quantity and quality of the attacked crop (Sharaby et al. 2013; Sabbour 2014). A diet selectivity index value greater than 1.0 indicates that the plant species is preferred by the grasshopper (Huang et al. 2016). Indeed, we found seven crops with a food selectivity index higher than 1.0. This Eyprepocnemidinae always selected high quantities of Cucurbitaceae and Solanaceae, suggesting, perhaps, that they contained some essential nutrient, lacking in the other host plants. According to Yousaf et al. (2018), plant species belonging to the Cucurbitaceae family contain several naturally related triterpenes, collectively known as cucurbitacins. These are constitutive or insect-induced allelochemicals and have been shown to have acute and sublethal toxicity, as well as deterrent effects for feeding and oviposition in insects (Agrawal et al. 1999; Tallamy et al. 1997). On the other hand, for many luperines (Coleoptera: Chrysomelidae: Galerucinae), cucurbitacins act as potent phagostimulants (Tallamy and Krischik 1989). As $H$. littorlis subsists almost entirely on plants in the Cucurbitaceae, which generally contain cucurbitacins, this suggests that cucurbitacins play a phagostimulant role in the diet of this Acridid. The following crops have been observed to suffer from $H$. littoralis during the study period: bottle gourd, pumpkin, tomato and melon. The feeding behavior of these insects through consumption rates can lead to increased damage to crop plants.

The niche breadth is the sum of different plant resources used by a species in an ecosystem (Zhang 2004). Generally, when food is abundant, herbivores tend to utilize the most available and suitable food resources which narrow their niche. In comparison, when food is lacking, herbivores will expand the range of plant species they consume, which widens their niche (Wang et al. 1996). According Capello et al. (2011), the diet breadth of grasshoppers varies from strict monophagy to extreme polyphagy. Between these extremes there are species exhibiting varying degrees of food selectivity. The food selection of $H$. littoralis in a cultivated environment in the Mzab valley was studied and the results showed that the locust used $40 \%$ of the trophic resources of the habitat and the diet selectivity index showed that our insect presents preferences for some plants and caused severe damage to seven cultivated dicotyledonous plants. According Le Gall and Gillon (1989), in well-established assemblages of grasshoppers, outside forests, one can find almost half graminivorous species 
and half for bivorous species. Moreover, Le Gall et al. (1998) noted that grasshoppers are not only graminivorous insects and they are not opportunistic feeders. Even if they potentially feed on a large number of plant species, they are highly selective among them. The selection of the Cucurbitaceae and Solanaceae by this Acrididae may be due to the water content of the plants. In fact, Latchininsky (2010) noted among the factors separating unpalatable from palatable food, the water content of the food plays a significant role. Specifically, based on our observation, we can say that Eyprepocnemidinae would be associated with areas that had a greater percentage of forbs and in particular the Cucurbitaceae and Solanaceae. Oviposition sites are another cue to the feeding behavior of newly hatched stages and reproductive adults (Le Gall et al. 1998). At Mzab valley, $S$. lycopersicum patches are good places for oviposition sites and can modify feeding behavior. In fact, during the study period, the larvae of $H$. littoralis are very abundant in tomato plots. In order to control these pests, it is essential to be able to predict their spatial distribution and to understand the factors that lead to outbreaks (Huang et al. 2015). Diet influences locust population dynamics (Ibanez et al. 2013), and the plant availability and feeding preferences are two major determinants of both locust diets and spatial distribution (Singer and Stireman 2001). Studies of grasshopper feeding habits and their interaction within plant communities are important for grasshopper control and protection of plant resources (Raymond et al. 2004; Lu et al. 2005). Our observations clearly showed that the Cucurbitaceae and Solanaceae influences the local presence and abundance of $H$. littoralis. This is undoubtedly due, in part, to the strong feeding preferences exhibited by this insect toward these two botanical families.

The present study showed that plants of the Cucurbitaceae and Solanaceae were most preferred. $H$. littoralis may act as a pest of some of the economically important plant species of those families in the study area. Since there has been no previous study of this nature involving phytophagous Acridid of Mzab valley, the present finding brings to light some observations, which may have major agro-economic importance. Future studies of the $H$. littoralis life cycle related to the plants on which it feeds under field conditions should be conducted to evaluate long-term responses that determine individual fitness, such as survival, development time, and fecundity.

\section{RESUME}

Zergoun Y., Guezoul O., Sekour M., Bouras N. et Holtz M.D. 2020. Sélection du régime alimentaire d'Heteracris littoralis dans un environnement cultivé, vallée du Mzab, Sahara septentrional, Algérie. Tunisian Journal of Plant Protection 15 (2): 69-80.

Cet article présente les résultats d'une étude sur le régime alimentaire d'Heteracris littoralis dans un agro-écosystème de la vallée du Mzab, Gouvernorat de Ghardaïa, Sahara septentrional, Algérie. Le régime alimentaire a été déterminé par l'analyse de fragments de plantes dans les fèces d' $H$. littoralis prélevés sur le terrain. Les individus analysés ont consommé 12 des 30 espèces végétales 
trouvées dans le milieu cultivé. Les résultats ont montré que ce criquet se nourrissait principalement de quelques plantes, telles que Lagenaria siceraria et Solanum lycopersicum, bien que leur régime alimentaire comprenne plus de 12 espèces végétales. La largeur de sa niche alimentaire était étroite $(0,51)$, avec un indice de sélectivité de 0,61 pour les femelles, 0,52 pour les mâles et 0,42 pour les larves. Les plantes consommées par les deux sexes et les larves n'étaient pas significativement différentes. Cette étude suggère que cet Eyprepocnemidinae est une espèce de criquet polyphage, malgré une préférence prononcée pour les Cucurbitacées et les Solanacées. Il en résulte une faible valeur de lindice de Berger-Parker $(0,24)$. Ces résultats sont d'une grande importance, augmentant la compréhension du comportement alimentaire des insectes herbivores et aide à contrôler les dommages causés par ces orthoptères.

Mots clés: Algérie, Heteracris littoralis, largeur de la niche, Sahara septentrional, sélection des aliments, vallée du Mzab

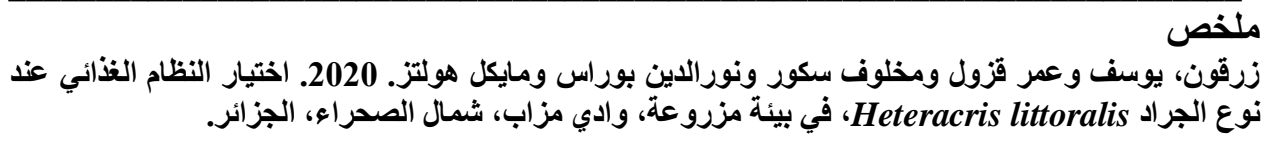
Tunisian Journal of Plant Protection 15 (2): 69-80.

يقّم هذا البحث نتائج در اسة عن غذاء نوع الجراد Heteracris littoralis في نظام بيئي زراعي في و ادي مزاب،

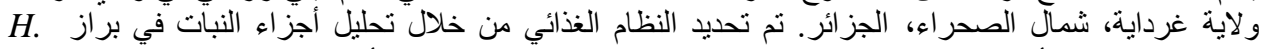
littoralis

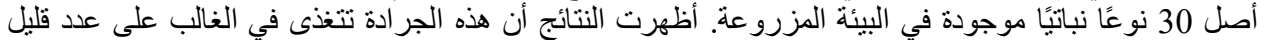

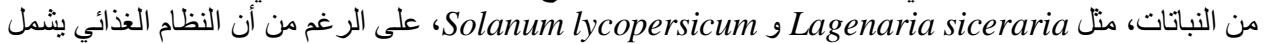

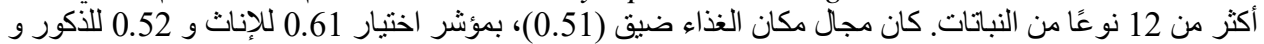

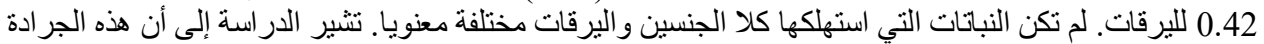

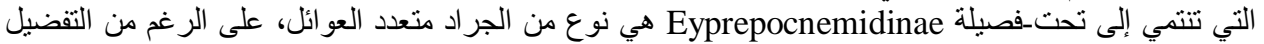

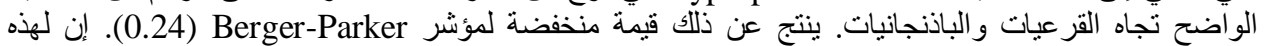

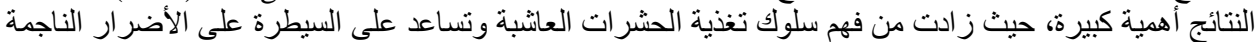
عن مستقيمات الأجنحة.

Heteracris، كلمات مفتاحية: اختيار الغذاء، الجزائر، شمال الصحراء، مجال مكان الغذاء، وادي مزاب littoralis

\section{LITERATURE CITED}

Agrawal, A., Gorski, P.M., and Tallamy, D.W. 1999. Polymorphism in plant defense against herbivory: Constitutive and induced resistance in Cucumis sativus. Journal of Chemical Ecology 25: 2285-2304.

Capello, S., De Wysiecki, M.L., and Marchese, M. 2011. Feeding patterns of the Aquatic Grasshopper Cornops aquaticum (Bruner) (Orthoptera: Acrididae) in the Middle Paraná River, Argentina. Neotropical Entomology 40: 170-175.

Capello, S., Marchese, M., and De Wysiecki, M.L. 2012. Feeding habits and trophic niche overlap of aquatic Orthoptera associated with macrophytes. Zoological Studies 51: 51-58.
Doumandji, S., Doumandji-Mitiche, B., Benzara, A., and Tarai, N. 1993. Méthode de la fenêtre proposée pour quantifier les prises de nourriture par les criquets. L'Entomologiste49: 213-216.

Doumandji, S.E., and Doumandji-Mitiche, B. 1994. Les criquets et les sauterelles. Acridologie. Office des Publications Universitaires, Alger, Algeria, 99 pp.

Duranton, J.F., Launois, M., Launois-Luong, M.H., and Lecoq, M. 1982. Manuel de prospection acridienne en zone tropicale sèche. De la théorie à la pratique. Ministère des Relations Extérieures, Coopération et développement / GERDAT: Paris, France, $695 \mathrm{pp}$. 
Hammer, O., Harper, D.A.T., and Ryan, P.D. 2014.PAST Paleontological Statistics Version $\quad 3.04$ http://folk.uio.no/ohammer/past.

Huang, X., McNeill, M., and Zhang, Z. 2015. Quantitative analysis of plant consumption and preference by Oedaleus asiaticus (Acrididae: Oedipodinae) in changed plant communities consisting of three grass species. Environmental Entomology45: 163170.

Huang, X., Wu, H., McNeill, M.R., Qin, X., Ma, J., Tu, X., Tu, X., Cao, G., Wang, G., Nong, X., and Zhang, Z. 2016.Quantitative analysis of diet structure by real-time PCR, reveals different feeding patterns by two dominant grasshopper species. Scientific Reports 6: 111.

Hurlbert, S.H. 1978. The Measurement of Niche Overlap and Some Relatives. Ecology5: 6777.

Ibanez, S., Manneville, O., Miquel, C., Taberlet, P., Valentini, A., Aubert S., Coissac, E., Colace, M.P., Duparc, Q., Lavorel, S., and Moretti, M. 2013. Plant functional traits reveal the relative contribution of habitat and food preferences to the diet of grasshoppers. Oecologia 173: 1459-1470.

Latchininsky, A.V. 2010. Locusts. Pages 288-297. In: Encyclopedia of animal behavior. M.D. Breed and J. Moore, Ed. Volume 2. Editions Academic press, Oxford, UK.

Launois-Luong, M.H. 1976. Méthode d'étude dans la nature du régime alimentaire du criquet migrateur Locusta migratoria (Sauss.). Annales de Zoologie Ecologie Animale 8: 25-32.

Le Gall, P., and Gillon, Y. 1989. Partage des ressources et spécialisation trophique chez les acridiens (Insecta: Orthoptera: Acridomorpha) non-graminivores dans une savane préforestière (Lamto, Côte d'Ivoire). Acta Oecologica/ Oecologia generalis 10: 51-74.

Le Gall, P., Mingouolo, E., and Bani, G. 1998. Diet of Zonocerus variegatus (L.) (Orthoptera - Acrididae) in cassava fields in Congo. Journal of Applied Entomology 122: 9-13.

Lehner, P. 1996. Handbook of ethological methods. Cambridge University Press, Cambridge, UK, 672 pp.

Levins, R. 1968. Evolution in changing environments. Princeton University Press. Princeton, New Jersey, USA, 132 pp.

Louveaux, A., Amedegnato, C., Poulain, S., and Desutter-Grandcolas, L. 2020. Orthoptères Acridomorpha de l'Afrique du Nord-Ouest.
Version 2.1. http://acrinwafrica.mnhn.fr [Date de consultation: 15 March 2020].

Lu, H., Yu. M., Zhang, L.S., Zhang, Z.H., and Long, R.J. 2005. Effects of foraging by different instars and density of Oedaleus asiaticus B. Bienko on forage yield. Acta Prataculture Science 31: 55-58.

Magurran, A. 1988. Ecological diversity and its measurement. Princeton University Press, Princeton, New Jersey, USA, 179 pp.

O.N.M. 2019. Office National de la Météorologie, Rapport sur les données climatiques de Ghardaïa, Algeria, 4 pp.

Otte, D., and Joern, A. 1977. On Feeding Patterns in Desert Grasshoppers and the Evolution of Specialized Diets. Proceedings of the Academy of Natural Sciences of Philadelphia 128: 89-126.

Ould El Hadj, M.D. 1999. Etude du régime alimentaire de quatre espèces d'Acrididae dans les conditions naturelles de la ferme de Jouifa dans la région de Beni Abbès (Sahara Septentrional). Annales de l'Institut National Agronomique, El Harrach 20: 69-75.

Pielou, E.C. 1969. An Introduction to Mathematical Ecology. Wiley Interscience. John Wiley and Sons, New York, USA, 286 pp.

Quezel, P., and Santa, S. 1962-1963. Nouvelle flore de l'Algérie et des régions désertiques méridionales. Editions C.N.R.S. Paris, France, $1165 \mathrm{pp}$.

Raymond, B.V., David, N.K., and Zhong, C. 2004. Performance of a generalist grasshopper on a C3 and a C4 grass: Compensation for the effects of elevated $\mathrm{CO}_{2}$ on plant nutritional quality. Oecologia 140: 96-103.

Sabbour, M.M.2014. Evaluating toxicity of nanoextracted Destruxin from Metarhizium anisopliae against the grasshopper Heteracris littoralis in Egypt. Journal of the Egyptian Academy of Environmental Development 15: 1-7.

Sharaby, A., Gesraha, M.A., and Montasser, S.A. 2013. Combined effect of some bio-agents against the grasshopper, Heteracris littoralis under semi-field condition. Journal of Agriculture and Veterinary Science 5: 2937.

Sharaby, A., Montaser, S.A., Mahmoud, Y.A., and Ibrahim, S.A. 2010. The possibility of rearing the grasshopper Heteracris littoralis (R.) on semi synthetic diets. Journal of Agriculture and Food Technology 1:1-7.

Sharaby, A., Sayed, A., Montaser, S.A. Mahmoud, Y.A., and Sobhi, A. 2012.Natural plant essential oils for controlling the grasshopper (Heteracris 
littoralis) and their pathological effects on the alimentary canal. Ecologia Balkanica 4: 39-52.

Singer, M., and Stireman, J. 2001. How foraging tactics determine host-plant use by a polyphagous caterpillar. Oecologia 129: 98105.

Tallamy, D.W., and Krischik, V.A. 1989 Variation and function of cucurbitacins in Cucurbita: an examination of current hypotheses. The American Naturalist 133: 766-786.

Tallamy, D.W., Stull, J., Ehresman, N.P., Gorski, P.M., and Mason, C.E. 1997. Cucurbitacins as feeding and oviposition deterrents to insects. Environmental Entomology 26: 678683.

Wang, S.P.2001. The dietary composition of fine wool sheep under different stocking rates and relationship between dietary diversity and range plant diversity of Artemisia frigida community under different stocking rate. Acta Ecologica Sinica 21: 237-243.

Wang, G.M., Zhou, Q.Q., and Zhong, W.Q. 1996. Trophic niches of four species of common small mammals in Inner Mongolia grassland and their relationships. Acta Ecologica Sinica 16: 71-76.

Yousaf, H.K., Shan, T., Chen, X., Ma, K., Shi, X., Desneux, N., Biondi, A., and Gao, X. 2018.Impact of the secondary plant metabolite Cucurbitacin $B$ on the demographical traits of the melon aphid, Aphis gossypii. Scientific Reports 8: 1-10.

Zhang, J.T. 2004. Succession analysis of plant communities in abandoned croplands in the Eastern Loess Plateau of China. Journal of Arid Environments 63: 458-474.

Zhang, L., Lecoq, M., Latchininsky, A., and Hunter, D. 2019. Locust and Grasshopper Management. The Annual Review of Entomology 64:15-34.

Zergoun, Y., Guezoul, O., Sekour, M., Bouras, N., and Holtz, M.D. 2018a. Species composition, abundance and diversity of grasshoppers (Insecta: Orthoptera) in three date palm groves in the Mzab valley, northern Sahara, Algeria. Ciência e Técnica Vitivinícola 33: 97-111.

Zergoun, Y., Guezoul, O., Sekour, M., Bouras, N., and Holtz, M.D. 2018b. Effects of temperatures and rainfall variability on the abundance and diversity of Caelifera (Insecta, Orthoptera) in three natural environments in the Mzab Valley, Septentrional Sahara (Algeria). Tunisian Journal of Plant Protection 13: 217-228.

Zergoun, Y., Guezoul, O., Sekour, M., Bouras, N., and Holtz, M.D. 2019. Acridid (Orthoptera: Caelifera) diversity in agriculture ecosystems at three locations in the Mzab valley, Septentrional Sahara, Algeria. Journal of Insect Biodiversity 9: 18-27. 